\title{
SWARD STRUCTURAL CHARACTERISTICS AND HERBAGE ACCUMULATION OF Panicum maximum cv. MOMBAÇA SUBJECTED TO ROTATIONAL STOCKING MANAGEMENTS
}

Sila Carneiro da Silva ${ }^{1 *}$; Adriana Amaral de Oliveira Bueno ${ }^{1}$; Roberta Aparecida Carnevalli ${ }^{1}$; Marina Castro Uebele ${ }^{1}$; Fernando Oliveira Bueno ${ }^{2}$; John Hodgson ${ }^{3}$; Cory Matthew ${ }^{3}$; Greg C. Arnold ${ }^{3}$; Jozivaldo Prudêncio Gomes de Morais ${ }^{2}$

${ }^{l}$ USP/ESALQ - Depto. de Zootecnia, C.P. 09 - 13418-900 - Piracicaba, SP - Brasil.

${ }^{2}$ UFSCAR, C.P. 153 - 13600 - 970 - Araras, SP - Brasil.

${ }^{3}$ Massey University, Private Bag 11222, Palmerston North, New Zealand.

*Corresponding author <scdsilva@esalq.usp.br>

ABSTRACT: Grazing strategies promote changes in sward structure that can affect patterns of herbage accumulation and sward flexibility to management. This experiment evaluated sward structural characteristics and herbage accumulation of Mombaça guinea grass (Panicum maximum Jacq. cv. Mombaça) subjected to rotational stocking managements. Treatments involved grazing when swards reached either 95 or $100 \%$ interception of the incident light (LI), to post-grazing heights of 30 and 50 $\mathrm{cm}$, and were allocated to $2,000 \mathrm{~m}^{2}$ paddocks according to a randomised complete block design in a $2 \times 2$ factorial arrangement with four replications, from January 2001 to February 2002. Sward canopy changed from a vertical to a more horizontal orientation as the light interception area index and height increased from post to pre-grazing. Leaf canopy height pre-grazing was stable throughout the year and around 90 and $115 \mathrm{~cm}$ for the $95 \%$ and $100 \%$ LI treatments respectively, indicating a potential for development and use of target-based grazing management practices. Herbage mass pre and postgrazing was lower for the $95 \%$ than the $100 \%$ LI treatments, but with higher proportion of leaf and lower proportions of stem and dead material. Treatment effects on herbage accumulation were cumulative and became more evident as the experiment progressed, with up to $6 \mathrm{tha}^{-1} \mathrm{DM}$ advantage to the $95 / 30$ treatment. Although based on a single year experiment, grazing management should aim for low herbage mass during the transition period from winter to spring in order to allow fast recovery of swards and favour herbage accumulation during the following growing season.

Key words: grazing management, leaf canopy height, leaf area index, light interception

\section{CARACTERÍSTICAS ESTRUTURAIS EACÚMULO DE FORRAGEM EM PASTOS DE Panicum maximum cv. MOMBAÇA SUBMETIDOS A ESTRATÉGIAS DE PASTEJO ROTATIVO}

RESUMO: Estratégias de pastejo promovem alterações na estrutura do dossel, afetando os padrões de acúmulo de forragem e flexibilidade ao manejo. O objetivo deste experimento foi avaliar as características estruturais do dossel e o acúmulo de forragem em pastos de capim-mombaça (Panicum maxium Jacq. cv. Mombaça) submetidos a estratégias de pastejo rotativo. Os tratamentos corresponderam a pastejos realizados quando os pastos atingiam 95 ou $100 \%$ de interceptação da luz incidente (IL) até alturas de resíduo de 30 e $50 \mathrm{~cm}$, e foram alocados às unidades experimentais (piquetes de $2000 \mathrm{~m}^{2}$ ) segundo um delineamento de blocos completos casualizados e arranjo fatorial $2 \times 2$, com quatro repetições, de janeiro de 2001 a fevereiro de 2002. O dossel passou de vertical para uma orientação mais horizontal à medida que o índice de área da folhagem e altura dos pastos aumentou durante a rebrota. A altura pré-pastejo do dossel mostrou-se estável durante o experimento e em torno de 90 e $115 \mathrm{~cm}$ para os tratamentos de 95 e $100 \%$ de IL, respectivamente, indicando potencial para o desenvolvimento e uso de práticas de manejo baseadas em metas de condição de pasto. A massa de forragem pré e pós-pastejo foi menor para os tratamentos de $95 \%$ em relação àqueles de $100 \%$ de IL, mas com maior proporção de folhas e menor proporção de colmos e material morto. Os efeitos dos tratamentos sobre o acúmulo de forragem foram cumulativos e se tornaram mais evidentes ao longo do experimento, com um valor de até $6 \mathrm{t} \mathrm{ha}^{-1}$ de MS superior para o tratamento 95/30. Embora baseado 
em experimento de um ano de duração, o manejo do pastejo deve priorizar baixos valores de massa de forragem durante a transição entre o inverno e a primavera como forma de permitir rápida recuperação dos pastos e favorecer o acúmulo de forragem na estação de crescimento seguinte.

Palavras-chave: manejo do pastejo, altura do dossel, índice de área foliar, interceptação luminosa.

\section{INTRODUCTION}

During the last 35 years there have been significant changes in grassland farming in Brazil. Overall, total grassland area has increased from around 150 to approximately 180 million hectares, with cultivated pastures increasing by over $300 \%$ at the expense of native pastures (Jank et al., 2005). Cultivated grasslands are mainly comprised of mono-specific, grassdominant pastures, with species and cultivars of Brachiaria and Panicum being the most used forage plants. On the other hand, knowledge and understanding of plant responses to grazing management have not evolved as quickly, with poor management and low animal productivity being a common feature under those circumstances (Da Silva, 2004).

Over the years, tropical pastures have been recognised by their high potential for dry matter production but labelled as producing herbage of low nutritive and feeding value (Mannetje, 1982; Hardy et al., 1997). This has generated the widespread view that tropical pastures are not capable of supporting medium to high levels of animal performance and productivity, which has resulted in serious distortions in the planning and management of tropical pastoral systems, including experimental agronomic and plant breeding programmes. However, recent studies have demonstrated that principles of grazing management and animal production from tropical pastures need to be reappraised (Da Silva \& Carvalho, 2005), and that understanding of functional responses of plants and animals to variations in sward state is essential (Hodgson, 1985). This approach has been adopted in the past for temperate forage species and resulted in significant progress towards the understanding of plant and animal responses to manipulation of sward conditions. In this context, variables like stocking rate, herbage allowance and defoliation interval are considered as means of achieving sward control and not as ends in themselves (Hodgson \& Da Silva, 2002). This represents a major conceptual change in the traditional approach towards research and management that was not applied to tropical pastures in Brazil until the late 1990's (e.g. Gomide, 1997).

The objective of this experiment was to evaluate sward structure, its pattern of change and herbage accumulation on a Panicum maximum Jacq. cv. Mombaça pasture subjected to strategies of rotational stocking management characterised by strict control of sward conditions.

\section{MATERIALAND METHODS}

\section{Site, experimental treatments and design}

The experiment was carried out in Araras, São Paulo State, Brazil ( $21^{\circ} 18^{\prime}$ S, $47^{\circ} 23^{\prime}$ W, 611 m a.s.1.), on a Panicum maximum cv. Mombaça pasture established in 1998 on a Haplic Acrisol (FAO, 2006) (Argissolo Vermelho distrófico latossólico, according to the Brazilian classification - EMBRAPA, 1999). Average soil chemical characteristics (Raij et al., 1986) were: $\mathrm{P}=9 \mathrm{mg} \mathrm{dm}^{-3}$ (ion-exchange resin extraction method); organic matter (O.M.) $=33 \mathrm{~g} \mathrm{dm}^{-3} ; \mathrm{pH}(0.01$ $\left.\mathrm{mol} \mathrm{L}^{-1} \mathrm{CaCl}_{2}\right)=5.3 ; \mathrm{K}=1.9 \mathrm{mmol}_{\mathrm{c}} \mathrm{dm}^{-3} ; \mathrm{Ca}=32$ $\mathrm{mmol}_{\mathrm{c}} \mathrm{dm}^{-3} ; \mathrm{Mg}=15 \mathrm{mmol}_{\mathrm{c}} \mathrm{dm}^{-3} ; \mathrm{H}+\mathrm{Al}=31 \mathrm{mmol}_{\mathrm{c}}$ $\mathrm{dm}^{-3}$; sum of bases $=49.5^{\mathrm{c}} \mathrm{mmol} \mathrm{dm}^{-3}$; cation exchange capacity $=80.4 \mathrm{mmol}_{\mathrm{c}} \mathrm{dm}^{-3}$; base saturation $=$ $61 \%$. Measurements started in January 2001 and finished in February 2002, totalling 395 days. Mean monthly rainfall, daily air temperature and daily solar radiation over the experimental period, recorded at a Meteorological Station located approximately $500 \mathrm{~m}$ from the experimental site, are shown in Figure 1. In relation to a 30-year normal, mean temperatures during the experimental period were 2 to $4^{\circ} \mathrm{C}$ higher, and rainfall was lower during first summer (Jan-Mar/01) and higher during late spring (Nov-Dec/01) and second summer (Jan-Feb/02).

Experimental treatments corresponded to combinations of two pre and two post-grazing conditions of a rotational stocking management with dairy cows. Pre-grazing conditions were defined by light interception levels of the sward canopy during regrowth (95 and $100 \% \mathrm{LI}$ ) and post-grazing conditions by residual sward heights (30 and $50 \mathrm{~cm}$ ), and named 95/30, 95/ $50,100 / 30$ and $100 / 50$. These were allocated to each of sixteen $2000 \mathrm{~m}^{2}$ paddocks according to a randomised complete block design, in a $2 \times 2$ factorial arrangement with four replications.

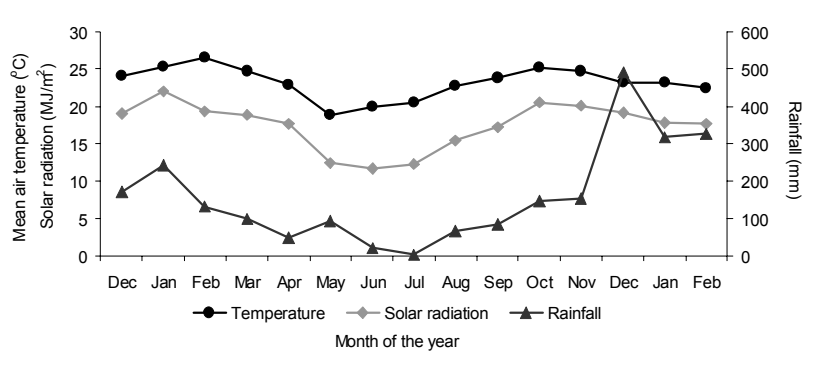

Figure 1 - Mean monthly rainfall, daily air temperature and daily solar radiation at the experimental site from December 2000 to February 2002. 


\section{Monitoring of experimental conditions and mea- surements}

During a pre-experimental preparatory phase, paddocks were rotationally grazed to a post-grazing residue of $30 \mathrm{~cm}$ every 30 days from September 2000. The post-grazing residues of 30 and $50 \mathrm{~cm}$ were created in December 2000, after a 2-month period of common rotational grazing, but still using a standard 30day rotation period. In early January 2001, after grazing to the target post-grazing heights and mowing some areas within some paddocks to ensure that the target residues had been created precisely, pre-grazing conditions started to be controlled and measurements were initiated.

Grazing was carried out by groups of 35 lactating Holstein dairy cows, but no measurements of animal performance were made. Animals were simply used as grazers and maximum grazing time in any paddock was 2 days. When necessary, a group of dry cows and heifers was used to augment stocking rate and finish the grazing session.

A 20:5:20 compound fertiliser $\left(\mathrm{N}: \mathrm{P}_{2} \mathrm{O}_{5}: \mathrm{K}_{2} \mathrm{O}\right)$ was applied to paddocks from the beginning of the preexperimental preparatory phase in September 2000. The amount used during the experimental period corresponded to $195 \mathrm{~kg} \mathrm{ha}^{-1}$ of nitrogen, applied to each paddock after grazing. Due to the variable length of the grazing cycles for individual paddocks, a consequence of the way treatments were defined, quantities of fertiliser were adjusted in order to ensure a relatively constant amount of fertiliser being used per paddock every two months. Fertiliser was used from October 2000 to April 2001 and October 2001 to February 2002 , the period of reliable rainfall and high temperatures (mid spring to early autumn 2000/01 and mid spring to mid summer 2001/02, respectively; Figure 1).

\section{Leaf canopy height, and size and orientation of the sward light interception area}

Leaf canopy height was measured through systematic readings on a $2 \mathrm{~m}$ ruler graduated in centimetres along pre-defined, zig-zag transect lines (16 points of measurement) covering the entire area of each paddock. Readings were taken from ground level considering the upper surface of the leaf canopy around the ruler as reference, even at times of the year when plants were reproductive and produced taller flowering stems (Carnevalli et al., 2006). Leaf canopy height was monitored regularly and canopy light interception measured pre and post-grazing and at every $20 \mathrm{~cm}$ increase in leaf canopy height from the post-grazing height of 30 or $50 \mathrm{~cm}$. After height measurements, areas with the average leaf canopy height were identi- fied along the transect line for each paddock and measurements of light interception carried out on six randomly selected locations from those areas using a canopy analyser (LAI 2000, LI-COR, Lincoln, Nebraska, USA) consistently in the afternoon period in the absence of direct solar radiation. In each location, one reading was taken above the canopy and five at ground level (optical sensor placed at the mid distance between tussocks), totalling six readings above the canopy and 30 at ground level per paddock. When light interception by the canopy reached $90 \%$, measurements were performed every two days until target specified pre-grazing conditions were achieved (95 and $100 \%$ LI). Measurements with the equipment under very dark conditions in tall swards resulted in a maximum light interception reading of $99 \%$ instead of $100 \%$ (Carnevalli et al., 2006), but the 100\% LI label is used throughout the text for ease of presentation.

The canopy analyser used (LAI 2000) also provided estimates of the light interception area and average orientation of the plant canopy (LI-COR, 1992). Since readings took into account all plant material above ground intercepting the incident light, not only leaf, they will be referred to as light interception area index (LIAI) rather than leaf area index (LAI), and used as the measure of canopy increase during regrowth. Similarly, the average angle of the LIAI is used as a general indicator of canopy orientation $\left(0^{\circ}=\right.$ horizontal and $90^{\circ}=$ vertical position).

\section{Herbage mass, botanical and morphological com- position}

Herbage mass was determined pre and postgrazing from cuts within three $1.47 \times 0.68 \mathrm{~m}\left(1 \mathrm{~m}^{2}\right)$ frames per paddock randomly allocated in areas that were representative of the average sward condition at the time of sampling (as described above for measurements of canopy light interception). Cuts were made at $20 \mathrm{~cm}$ from ground level at different areas of paddocks every sampling procedure in order not to damage the plant stand and impair future sampling procedures, given the tall-tufted growth habit of the grass species under study.

After cutting, samples were weighed fresh and sub-sampled, with sub-samples also weighed fresh. Sub-samples were hand dissected into live leaf (lamina), live stem (leaf sheath + stem), dead material and weeds. Each component was dried separately in a forced-draught oven at $65^{\circ} \mathrm{C}$ for $48 \mathrm{~h}$ and then weighed. Herbage dry matter content and its morphological composition were calculated from the dry weights of sub-samples and their components, and herbage mass calculated accordingly. Weeds comprised less than $5 \%$ of the samples, so swards were consid- 
ered as pure Mombaça guineagrass stands. Herbage accumulation was calculated as the difference between pre-grazing and the preceding post-grazing herbage mass.

\section{Data processing and analysis}

Because pre-grazing conditions were defined in terms of sward canopy light interception levels, grazing dates and rest periods for each paddock were highly dependent on the prevailing environmental growth conditions and, therefore, variable. In order to establish a common basis of comparison for identifying possible patterns of change in herbage accumulation and grouping of data for uniformity in the analysis of variance, herbage accumulation rates for each paddock in every grazing cycle throughout the experiment were pooled for individual treatments $(95 / 30,95 /$ 50, 100/30 and 100/50) and Fourier series curves derived to describe patterns of herbage accumulation (Lambert et al., 1986). Curves were fitted as mixed effect models allowing variability within each paddock to be smaller than variability between paddocks. Potential correlation through time between residuals on the same paddock was allowed for by a continuous auto-correlation model. Models were fitted as linear in $\sin (\mathrm{x})$ and $\cos (\mathrm{x})$, then the equality $\sin (\mathrm{A}+\mathrm{B})=(\sin$ $\mathrm{A} \cos \mathrm{B})+(\cos \mathrm{A} \sin \mathrm{B})$ was used to transform them to the form $y=a+b(x)+c \sin (0.0172(x+d))$. In this equation $\mathrm{a}, \mathrm{b}, \mathrm{c}$ and $\mathrm{d}$ are coefficients; $\mathrm{x}$ is the Julian day of the experiment ( 1 to 395 ); $0.0172=2 \pi / 365$, a factor used for converting days to radians; and y is the rate of herbage accumulation for day $\mathrm{x}\left(\mathrm{kg} \mathrm{ha}^{-1}\right.$ day $^{-1}$ of DM).
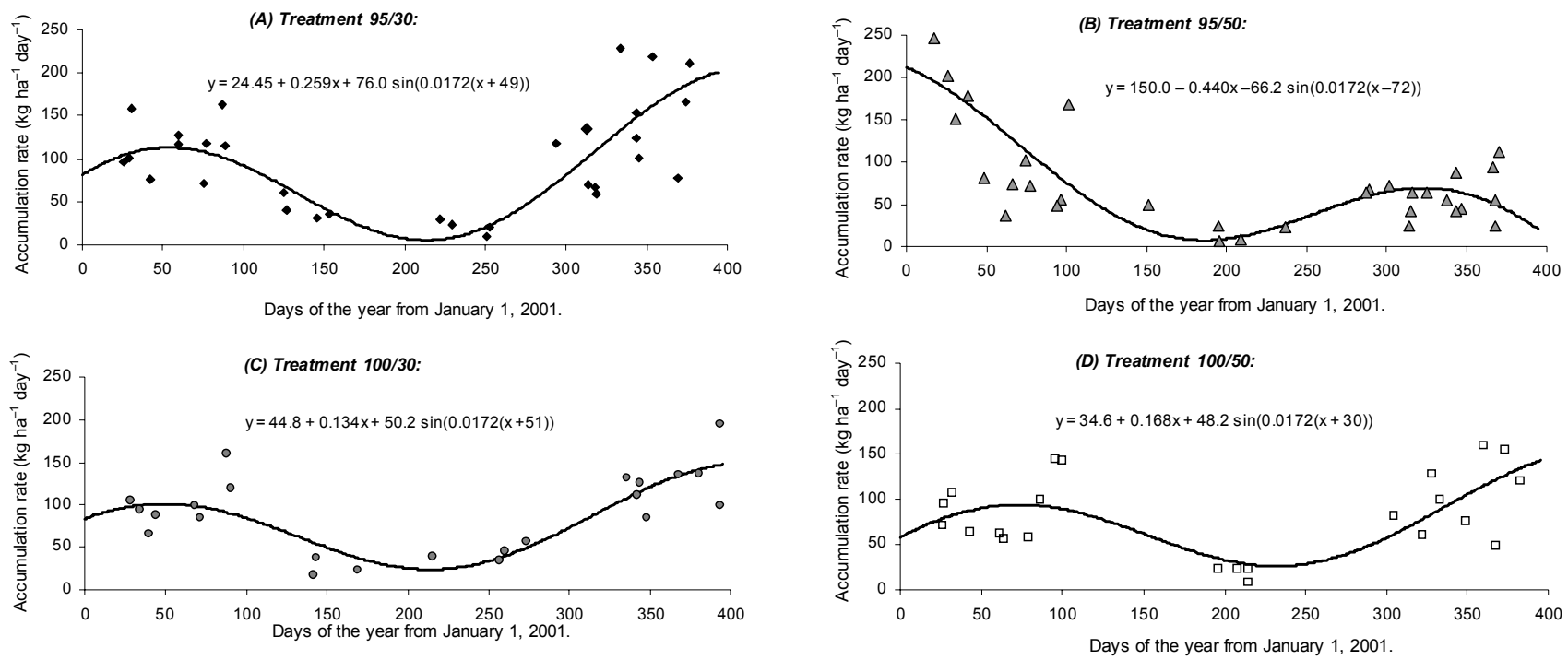

Figure 2 - Plot of fitted Fourier curves of herbage accumulation rate data of Panicum maximum cv. Mombaça subjected to rotational stocking managements from January 2001 to February 2002.

Sci. Agric. (Piracicaba, Braz.), v.66, n.1, p.8-19, January/February 2009
Visual assessment of the fitted curves (Figure 2) identified four periods within which general behaviour was similar but represented changes in patterns of herbage accumulation (summer 1 = JanuaryMarch/01; autumn-winter $=$ April-September/01; spring $=$ October-December/01; and early-summer 2 = January/02), so data were grouped accordingly and values for individual paddocks weighed for the number of records within seasons. Analysis of variance was carried out on the grouped data using the Mixed Procedure of SAS ${ }^{\circledR}$ (Statistical Analysis System). The choice of the covariance matrix was made using the Akaike Information Criterion (AIC) (Wolfinger, 1993), and analysis performed considering light interception pregrazing, post-grazing height, season of the year and their interactions as fixed effects and blocks as a random effect. When appropriate, treatment means were calculated using the "LSMEANS" statement, and comparisons made with "PDIFF" based on a Student test $(p<0.05)$. Data on total dry matter accumulation for the experiment were analysed using the GLM Procedure of SAS.

\section{RESULTS}

\section{Monitoring and control of sward conditions}

Sward conditions pre and post-grazing were controlled by monitoring canopy light interception (LI) and height throughout every regrowth period during the experiment. Since these were controlled variables, data are presented using only descriptive statistics (means and standard error of the difference - s.e.d.). 
Leaf canopy height pre-grazing was lower for the $95 \%$ than the $100 \%$ LI treatments $(88.7$ vs 115.4 $\mathrm{cm}$, s.e.d. $=2.09)$ and values were relatively constant for the $95 \%$ but increased for the $100 \%$ LI treatments throughout the year (109.8 to $124.3 \mathrm{~cm}$ from summer 1 to early summer 2, respectively; Figure 3). The nominal 30 and $50 \mathrm{~cm}$ post-grazing residue targets corresponded to actual average values of 33.7, 50.0, 42.0 and $54.3 \mathrm{~cm}$, s.e.d. $=0.92$, for the $95 / 30,95 / 50,100 /$ 30 and 100/50 treatments, respectively, indicating the difficulty of controlling post-grazing residue (particularly $30 \mathrm{~cm}$ ) when grazing was associated with the $100 \%$ LI pre-grazing condition.

Grazing to $30 \mathrm{~cm}$ residue resulted in a lower and more vertical LIAI after grazing than to $50 \mathrm{~cm}$ residue $(1.43 v s 1.90$, s.e.d. $=0.078$, and $69.1 v s$ $61.2^{\circ}$, s.e.d. $=2.05$, for LIAI and LIAI angle, respectively; Figures 4 and 5). Canopy size increased and LIAI angle decreased steadily during regrowth until the next grazing, when LIAI was lower and LIAI angle higher for the $95 \%$ than the $100 \%$ LI treatments $(4.20$ vs 5.50 , s.e.d. $=0.114$, and $50.6 v s 46.5^{\circ}$, s.e.d. $=$ 1.65 , respectively), highlighting a consistent pattern of change in canopy characteristics during regrowth. As a result, canopy light interception was lower for the

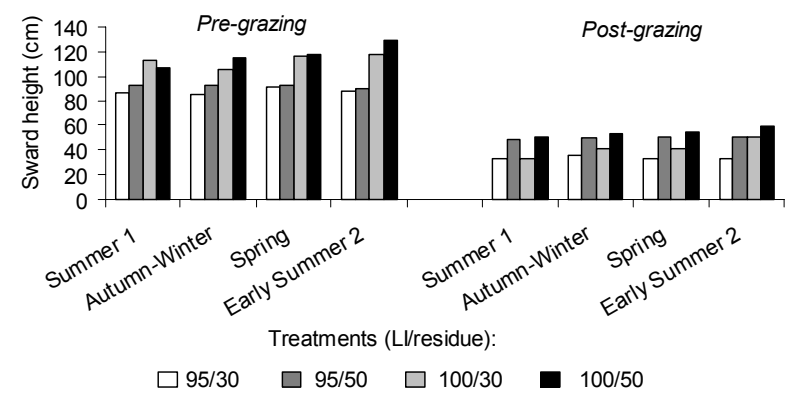

Figure 3 - Leaf canopy height pre and post-grazing of Panicum maximum cv. Mombaça swards subjected to rotational stocking managements from January 2001 to February 2002.

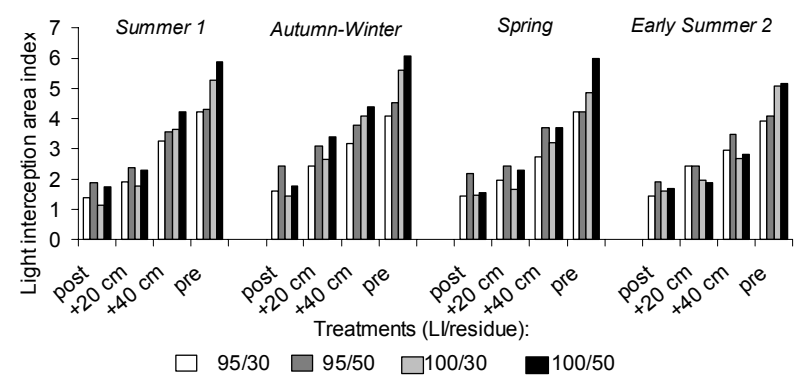

Figure 4 - Sward light interception area index (LIAI) during regrowth of Panicum maximum cv. Mombaça swards subjected to rotational stocking managements from January 2001 to February 2002.
$30 \mathrm{~cm}$ than the $50 \mathrm{~cm}$ residue treatments soon after grazing $(62.3$ vs $73.2 \%$, s.e.d. $=1.43)$ and increased steadily during regrowth until the next grazing, when average values for the 95/30,95/50,100/30 and 100/ 50 treatments were $95.3,95.5,98.1$ and $98.9 \%$, s.e.d. $=1.60$, respectively (Figure 6).

\section{Sward characteristics pre and post-grazing}

\section{Herbage mass}

During the first three months of the experimental period, in summer 1 , herbage mass pre (Table 1 ) and post-grazing (Table 2) varied only with postgrazing residue. Contrasts between treatments became more evident from autumn-winter onwards, particularly for the post-grazing herbage mass, when differences between LI treatments started to be noticed and persisted until the end of the experiment. Herbage mass pre-grazing did not vary for the $95 \%$ LI treatments but increased for the $100 \%$ LI treatments as the experiment progressed $(p<0.0001)$. The $50 \mathrm{~cm}$ post-grazing residue treatments resulted in higher herbage mass pre-grazing than the $30 \mathrm{~cm}$ treatments during summer 1 and autumn-winter, these differences disappearing in spring and early-summer $2(p=0.0247)$.

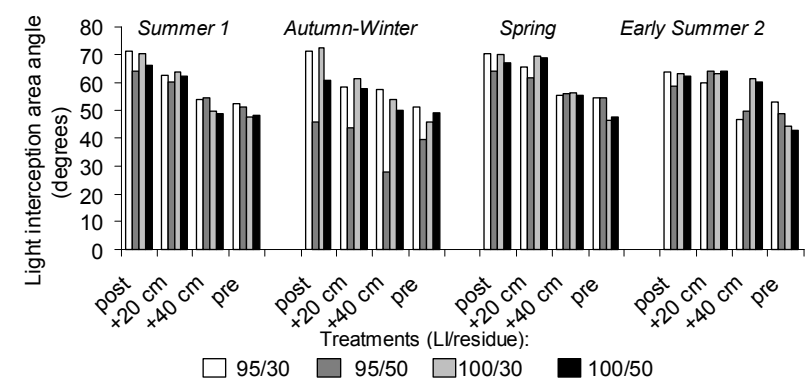

Figure 5 - Sward light interception area orientation (LIAI angle) during regrowth of Panicum maximum cv. Mombaça swards subjected to rotational stocking managements from January 2001 to February 2002.

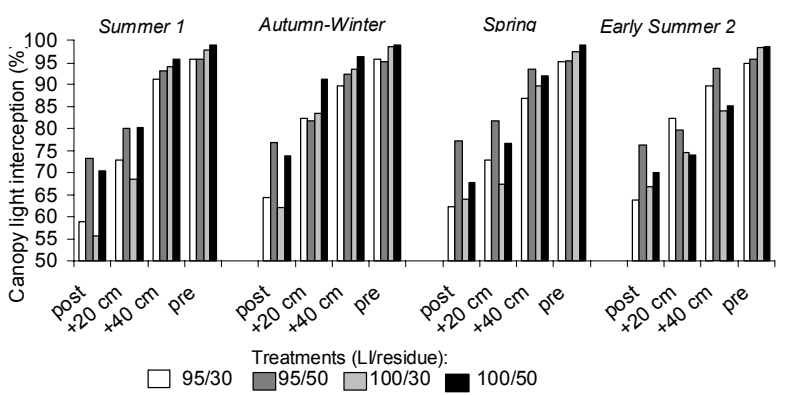

Figure 6 - Sward light interception during regrowth of Panicum maximum cv. Mombaça swards subjected to rotational stocking managements from January 2001 to February 2002. 
Table 1 - Herbage mass pre-grazing of Mombaça grass swards subjected to rotational stocking managements from January 2001 to February 2002.

\begin{tabular}{|c|c|c|c|c|c|}
\hline \multirow{2}{*}{ Season of the year } & \multicolumn{2}{|c|}{ Sward light interception ${ }^{1}(\%)$} & \multicolumn{2}{|c|}{ Residue $(\mathrm{cm})$} & \multirow{2}{*}{ S.E.D. ${ }^{2}$} \\
\hline & 95 & 100 & 30 & 50 & \\
\hline & (n. & $\ldots-\ldots k$ & - & 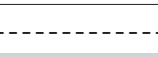 & \\
\hline Summer 1 & $5730 \mathrm{Aa}$ & $5600 \mathrm{Ac}$ & $4940 \mathrm{Bb}$ & $6390 \mathrm{Ab}$ & 250 \\
\hline Autumn-Winter & $5430 \mathrm{Ba}$ & $7150 \mathrm{Ab}$ & $5150 \mathrm{Bb}$ & 7420 Aa & 509 \\
\hline Spring & $5180 \mathrm{Ba}$ & $8830 \mathrm{Aa}$ & $6690 \mathrm{Aa}$ & $7330 \mathrm{Aa}$ & 348 \\
\hline Early-Summer 2 & $5500 \mathrm{Ba}$ & $8410 \mathrm{Aa}$ & $6800 \mathrm{Aa}$ & 7110 Aab & 666 \\
\hline
\end{tabular}

${ }^{1}$ Means followed by the same lower case letters in columns and upper case letters in rows for either sward light interception or residue are not different $(p>0.05) .{ }^{2}$ Standard error of the difference.

In general, herbage mass post-grazing was highest for treatment 100/50 and lowest for treatment $95 / 30$, with intermediate values recorded for treatments $95 / 50$ and $100 / 30$. This pattern of contrast between treatments became more evident as the experiment progressed, with treatment effects being first noticed in terms of post-grazing residue (summer 1) and later in terms of both post-grazing residue and LI (from autumn/winter onwards) ( $p=0.0243)$.

\section{Proportion of leaf}

Swards grazed to $30 \mathrm{~cm}$ presented higher proportions of leaf pre-grazing than those grazed to 50 cm $(64.5$ vs $58.0 \%$, s.e.d. $=2.05 ; p=0.0112)$. During the beginning of the experiment, in summer 1 , the proportion of leaf pre-grazing was high and larger values were recorded for the $100 \%$ in relation to the $95 \%$ LI treatments (Table 3). In autumn/winter recorded values decreased for both LI treatments and there was no difference between 95 and 100\% LI. From the beginning of the next growing season (spring onwards) LI treatments behaved differently, with leaf proportion pre-grazing increasing for the $95 \%$ and remaining stable for the $100 \%$ LI treatments $(p=0.0021)$.

The proportion of leaf post-grazing during the first three months of the experiment (summer 1) was higher for $95 / 50$ and lower for the 100/30 treatments, with intermediate values recorded for treatments 95/ 30 and 100/50 (Table 4). During autumn/winter and spring a clear contrast between LI treatments became evident with higher proportions of leaf post-grazing recorded for the 95 than the $100 \%$ LI treatments. At the end of the experiment, in early-summer 2, the contrast between LI treatments was still evident, but highest values were recorded for treatment $95 / 30$, resulting in differences between post-grazing residue treatments $(p=0.0384)$.

\section{Proportion of stem}

The proportion of stem pre-grazing was consistently lower for the $30 \mathrm{~cm}$ than the $50 \mathrm{~cm}$ residue treatments throughout the experimental period, except
Table 2 - Herbage mass post-grazing of Mombaça grass swards subjected to rotational stocking managements from January 2001 to February 2002.

\begin{tabular}{|c|c|c|}
\hline \multirow{2}{*}{ Residue (cm) } & \multicolumn{2}{|c|}{ Sward light interception (\%) } \\
\hline & 95 & 100 \\
\hline \multicolumn{3}{|c|}{ Summer $1\left(\mathrm{~kg} \mathrm{ha}^{-1} \mathrm{DM}\right)^{1}$} \\
\hline 30 & $1340 \mathrm{~B}^{\prime}$ & $1760 \mathrm{~B}^{\prime}$ \\
\hline 50 & $3550 \mathrm{~A}^{\prime}$ & $4000 \mathrm{~A}^{\prime}$ \\
\hline \multicolumn{3}{|c|}{ s.e.d $\mathrm{d}^{2}$. interaction $=332$} \\
\hline \multicolumn{3}{|c|}{ Autumn-Winter $\left(\mathrm{kg} \mathrm{ha}^{-1} \mathrm{DM}\right)$} \\
\hline 30 & $2010 \mathrm{C}^{\prime}$ & $3030 \mathrm{BC}^{\prime}$ \\
\hline 50 & $3740 \mathrm{~B}^{\prime}$ & $5340 \mathrm{~A}^{\prime}$ \\
\hline \multicolumn{3}{|c|}{ s.e.d. interaction $=515$} \\
\hline & \multicolumn{2}{|c|}{ Spring $\left(\mathrm{kg} \mathrm{ha}^{-1} \mathrm{DM}\right)$} \\
\hline 30 & $1820 \mathrm{D}^{\prime}$ & $2910 \mathrm{C}^{\prime}$ \\
\hline \multirow[t]{3}{*}{50} & $4280 \mathrm{~B}^{\prime}$ & $4910 \mathrm{~A}^{\prime}$ \\
\hline & \multicolumn{2}{|c|}{ s.e.d. interaction $=185$} \\
\hline & \multicolumn{2}{|c|}{ Early-Summer $2\left(\mathrm{~kg} \mathrm{ha}^{-1} \mathrm{DM}\right)$} \\
\hline 30 & $1600 \mathrm{C}^{\prime}$ & $4320 \mathrm{AB}^{\prime}$ \\
\hline 50 & $3900 \mathrm{~B}^{\prime}$ & $4800 \mathrm{~A}^{\prime}$ \\
\hline
\end{tabular}

${ }^{1}$ Treatment means followed by the same upper case letter with (') within seasons are not different $(p>0.05) .{ }^{2}$ Standard error of the difference.

Table 3 - Proportion of leaf pre-grazing of Mombaça grass swards grazed at either 95 or $100 \%$ canopy light interception from January 2001 to February 2002.

\begin{tabular}{|c|c|c|c|}
\hline \multirow{2}{*}{ Season of the year } & \multicolumn{3}{|c|}{ Sward light interception ${ }^{1}(\%)$} \\
\hline & 95 & 100 & S.E.D. ${ }^{2}$ \\
\hline & \multicolumn{3}{|c|}{ - } \\
\hline Summer 1 & $62.2 \mathrm{Bb}$ & $69.4 \mathrm{Aa}$ & 2.12 \\
\hline Autumn-Winter & $58.4 \mathrm{Ab}$ & $53.3 \mathrm{Ab}$ & 3.73 \\
\hline Spring & $69.2 \mathrm{Aa}$ & $57.2 \mathrm{Bb}$ & 3.58 \\
\hline Early-Summer 2 & $62.7 \mathrm{Aab}$ & $57.6 \mathrm{Ab}$ & 2.97 \\
\hline
\end{tabular}

${ }^{1}$ Means followed by the same lower case letters in columns and upper case letters in rows are not different $(p>0.05) .{ }^{2}$ Standard error of the difference. 
Table 4 - Proportion of leaf post-grazing of Mombaça grass swards subjected to rotational stocking managements from January 2001 to February 2002.

\begin{tabular}{|c|c|c|}
\hline \multirow{2}{*}{ Residue (cm) } & \multicolumn{2}{|c|}{ Sward light interception $(\%)$} \\
\hline & 95 & 100 \\
\hline \multicolumn{3}{|c|}{ Summer $1(\%)^{1}$} \\
\hline 30 & $41.9 \mathrm{AB}^{\prime}$ & $34.0 \mathrm{~B}^{\prime}$ \\
\hline 50 & $43.2 \mathrm{~A}^{\prime}$ & $41.7 \mathrm{AB}^{\prime}$ \\
\hline \multicolumn{3}{|c|}{ s.e.d $\mathrm{d}^{2}$. interaction $=4.07$} \\
\hline \multicolumn{3}{|c|}{ Autumn-Winter (\%) } \\
\hline 30 & $39.7 \mathrm{~A}^{\prime}$ & $29.9 \mathrm{~B}^{\prime}$ \\
\hline 50 & $41.3 \mathrm{~A}^{\prime}$ & $29.2 \mathrm{~B}^{\prime}$ \\
\hline \multicolumn{3}{|c|}{ s.e.d. interaction $=2.57$} \\
\hline \multicolumn{3}{|c|}{ Spring $(\%)$} \\
\hline 30 & $48.5 \mathrm{~A}^{\prime}$ & $39.5 \mathrm{AB}^{\prime}$ \\
\hline 50 & $46.5 \mathrm{~A}^{\prime}$ & $35.3 \mathrm{~B}^{\prime}$ \\
\hline \multicolumn{3}{|c|}{ s.e.d. interaction $=4.48$} \\
\hline \multicolumn{3}{|c|}{ Early-Summer $2(\%)$} \\
\hline 30 & $57.3 \mathrm{~A}^{\prime}$ & $30.3 \mathrm{C}^{\prime}$ \\
\hline \multirow[t]{2}{*}{50} & 39.9 B' & $30.9 \mathrm{C}^{\prime}$ \\
\hline & \multicolumn{2}{|c|}{ s.e.d. interaction $=3.63$} \\
\hline
\end{tabular}

${ }^{1}$ Treatment means followed by the same upper case letter with (') within seasons are not different $(p>0.05)$. ${ }^{2}$ Standard error of the difference.

during early-summer 2 (Table 5). Treatment 95/30 showed the lowest proportions of stem pre-grazing during the experiment, except during early-summer 2 . At the beginning of the experiment, in summer 1, treatment 95/50 had the highest values, but during autumn/ winter highest values were recorded for treatment 100/ 50. In spring, treatment 100/50 still showed the highest values for stem pre-grazing, but a contrast between LI treatments was detected, with $95 \%$ LI showing lower values than $100 \%$ LI. During early-summer 2 all contrasts disappeared $(p=0.0258)$.

There was no difference in proportion of stem post-grazing between treatments during summer 1 (Table 6). On the other hand, from autumn/winter until early-summer 2, lowest values of stem post-grazing were consistently recorded for treatment $95 / 30$, with lower values recorded for the $95 \%$ than the $100 \% \mathrm{LI}$ treatments, particularly treatment $100 / 50(p=0.0039)$.

\section{Proportion of dead material}

The proportion of dead material pre-grazing was higher for the $95 \%$ than the $100 \%$ LI treatments during summer 1 , with highest values recorded for the 95/30 and lowest for the 100/30 treatments (Table 7). Differences disappeared during autumn/winter but were detected again at the beginning of the next spring growing season, when lower values were recorded for the
Table 5 - Proportion of stem pre-grazing of Mombaça grass swards subjected to rotational stocking managements from January 2001 to February 2002.

\begin{tabular}{|c|c|c|}
\hline \multirow{2}{*}{ Residue (cm) } & \multicolumn{2}{|c|}{ Sward light interception (\%) } \\
\hline & 95 & 100 \\
\hline \multicolumn{3}{|c|}{ Summer $1(\%)^{1}$} \\
\hline 30 & $12.1 \mathrm{C}^{\prime}$ & $18.3 \mathrm{~B}^{\prime}$ \\
\hline \multirow[t]{3}{*}{50} & $28.6 \mathrm{~A}^{\prime}$ & $21.4 \mathrm{~B}^{\prime}$ \\
\hline & \multicolumn{2}{|c|}{ s.e. $\mathrm{d}^{2}$. interaction $=2.95$} \\
\hline & \multicolumn{2}{|c|}{ Autumn-Winter (\%) } \\
\hline 30 & $18.4 \mathrm{C}^{\prime}$ & $24.6 \mathrm{BC}^{\prime}$ \\
\hline \multirow[t]{3}{*}{50} & $29.5 \mathrm{AB}^{\prime}$ & $34.2 \mathrm{~A}^{\prime}$ \\
\hline & \multicolumn{2}{|c|}{ s.e.d. interaction $=4.51$} \\
\hline & \multicolumn{2}{|c|}{ Spring $(\%)$} \\
\hline 30 & $11.6 \mathrm{C}^{\prime}$ & $17.1 \mathrm{~B}^{\prime}$ \\
\hline \multirow[t]{3}{*}{50} & $13.3 \mathrm{C}^{\prime}$ & $20.3 \mathrm{~A}^{\prime}$ \\
\hline & \multicolumn{2}{|c|}{ s.e.d. interaction $=1.41$} \\
\hline & \multicolumn{2}{|c|}{ Early-Summer $2(\%)$} \\
\hline 30 & $24.7 \mathrm{~A}^{\prime}$ & $29.5 \mathrm{~A}^{\prime}$ \\
\hline \multirow[t]{2}{*}{50} & $22.5 \mathrm{~A}^{\prime}$ & $27.3 \mathrm{~A}^{\prime}$ \\
\hline & \multicolumn{2}{|c|}{ s.e.d. interaction $=4.17$} \\
\hline
\end{tabular}

${ }^{1}$ Treatment means followed by the same upper case letter with (') within seasons are not different $(p>0.05)$. ${ }^{2}$ Standard error of the difference.

Table 6 - Proportion of stem post-grazing of Mombaça grass swards subjected to rotational stocking managements from January 2001 to February 2002.

\begin{tabular}{|c|c|c|}
\hline \multirow{2}{*}{ Residue (cm) } & \multicolumn{2}{|c|}{ Sward light interception (\%) } \\
\hline & 95 & 100 \\
\hline \multicolumn{3}{|c|}{ Summer $1(\%)^{1}$} \\
\hline 30 & $33.8 \mathrm{~A}^{\prime}$ & $39.3 \mathrm{~A}^{\prime}$ \\
\hline 50 & $36.5 \mathrm{~A}^{\prime}$ & $36.4 \mathrm{~A}^{\prime}$ \\
\hline \multicolumn{3}{|c|}{ s.e. $d^{2}$. interaction $=3.97$} \\
\hline \multicolumn{3}{|c|}{ Autumn-Winter (\%) } \\
\hline 30 & $21.2 \mathrm{C}^{\prime}$ & $31.4 \mathrm{AB}^{\prime}$ \\
\hline 50 & $27.6 \mathrm{BC}^{\prime}$ & $38.7 \mathrm{~A}^{\prime}$ \\
\hline \multicolumn{3}{|c|}{ s.e.d. interaction $=3.97$} \\
\hline \multicolumn{3}{|c|}{ Spring $(\%)$} \\
\hline 30 & $17.2 \mathrm{~B}^{\prime}$ & $22.0 \mathrm{AB}^{\prime}$ \\
\hline 50 & $16.8 \mathrm{~B}^{\prime}$ & $25.3 \mathrm{~A}^{\prime}$ \\
\hline \multicolumn{3}{|c|}{ s.e.d. interaction $=3.97$} \\
\hline \multicolumn{3}{|c|}{ Early-Summer $2(\%)$} \\
\hline 30 & $19.2 \mathrm{C}^{\prime}$ & $45.2 \mathrm{~A}^{\prime}$ \\
\hline 50 & $35.8 \mathrm{~B}^{\prime}$ & $42.6 \mathrm{AB}^{\prime}$ \\
\hline
\end{tabular}

${ }^{1}$ Treatment means followed by the same upper case letter with (') within seasons are not different $(p>0.05)$. ${ }^{2}$ Standard error of the difference. 
$95 / 30$ in relation to all other treatments. At the end of the experiment, in early-summer 2, differences between treatments disappeared and recorded values were lower in relation to those recorded during spring ( $p=$ 0.0073).

At post-grazing, the proportion of dead material varied only with season of the year $(p<0.0001)$, with lowest values recorded during both summers and highest during autumn-winter and spring $(22.1,34.6$, 37.0 and $25.3 \%$, s.e.d. $=2.33$, for summer 1 , autumnwinter, spring and early summer 2 , respectively).

\section{Herbage accumulation}

The experimental period comprised half of the 2000/2001 (January-March/01) and half of the 2001/ 2002 (October/01-January/02) growth cycles (Figure 1). Fitting of Fourier series curves indicated clearly that treatment $95 / 50$ behaved differently from the other three treatments, and treatments $100 / 30$ and $100 / 50$ were similar (Figure 2). The ratio of maximum to minimum herbage accumulation rate was larger for the 95/ 30 and $95 / 50$ than for the $100 / 30$ and $100 / 50$ treatments in both 2000/2001 (21.4 and 30.7; 4.2 and 3.6) and 2001/2002 (38.1 and 9.9; 6.2 and 5.4, respectively), indicating pronounced but different patterns of seasonality of production. During the 2000/2001 and

Table 7 - Proportion of dead material pre-grazing of Mombaça grass swards subjected to rotational stocking managements from January 2001 to February 2002.

\begin{tabular}{|c|c|c|}
\hline \multirow{2}{*}{ Residue $(\mathrm{cm})$} & \multicolumn{2}{|c|}{ Sward light interception (\%) } \\
\hline & 95 & 100 \\
\hline \multicolumn{3}{|c|}{ Summer $1(\%)^{1}$} \\
\hline 30 & $20.8 \mathrm{~A}^{\prime}$ & $5.9 \mathrm{C}^{\prime}$ \\
\hline 50 & $13.6 \mathrm{AB}^{\prime}$ & $10.9 \mathrm{BC}^{\prime}$ \\
\hline \multicolumn{3}{|c|}{ s.e. $d^{2}$. interaction $=3.66$} \\
\hline \multicolumn{3}{|c|}{ Autumn-Winter (\%) } \\
\hline 30 & $15.5 \mathrm{~A}^{\prime}$ & $17.9 \mathrm{~A}^{\prime}$ \\
\hline 50 & $19.7 \mathrm{~A}^{\prime}$ & $16.7 \mathrm{~A}^{\prime}$ \\
\hline \multicolumn{3}{|c|}{ s.e.d. interaction $=3.66$} \\
\hline \multicolumn{3}{|c|}{ Spring $(\%)$} \\
\hline 30 & $12.2 \mathrm{~B}^{\prime}$ & $26.6 \mathrm{~A}^{\prime}$ \\
\hline 50 & $24.4 \mathrm{~A}^{\prime}$ & $21.5 \mathrm{~A}^{\prime}$ \\
\hline \multicolumn{3}{|c|}{ s.e.d. interaction $=3.66$} \\
\hline \multicolumn{3}{|c|}{ Early-Summer $2(\%)$} \\
\hline 30 & $9.8 \mathrm{~A}^{\prime}$ & $11.9 \mathrm{~A}^{\prime}$ \\
\hline 50 & $16.7 \mathrm{~A}^{\prime}$ & $13.6 \mathrm{~A}^{\prime}$ \\
\hline
\end{tabular}

${ }^{1}$ Treatment means followed by the same upper case letter with (') within seasons are not different $(p>0.05)$. ${ }^{2}$ Standard error of the difference.
2001/2002 seasons maximum herbage accumulation rate occurred at day 54, 0, 49 and 73 and 395, 323, 395 and 395 , respectively, with minimum values recorded at day 213, 186, 214 and 232 for treatments $95 / 30,95 / 50,100 / 30$ and 100/50, respectively. Treatment $95 / 50$ resulted in an overall decline in herbage accumulation throughout the year, while the other three treatments showed an overall increase (linear coefficient of the fitted Fourier curves), especially 95/30, indicating the occurrence of different cumulative treatment effects as the experiment progressed. Predicted values of average herbage accumulation rate for the experiment (calculated using the linear component of the fitted curves for the mid point of the experimental period - day 198) were $75.8,62.9,71.3$ and $67.9 \mathrm{~kg}$ $\mathrm{ha}^{-1} \mathrm{DM}$ for treatments $95 / 30,95 / 50,100 / 30$ and $100 /$ 50 , respectively.

Total dry matter accumulation for the entire experiment was larger $(p=0.0558)$ for the $30 \mathrm{~cm}$ than the $50 \mathrm{~cm}$ residue treatments $\left(27160\right.$ vs $21430 \mathrm{~kg} \mathrm{ha}^{-1}$, s.e.d. $=2609)$ and there was a trend $(p=0.0828)$ for higher accumulation for the $95 / 30$ than the $95 / 50$ treatment $\left(28260\right.$ and $21060 \mathrm{~kg} \mathrm{ha}^{-1}$, s.e.d. $=3690$, respectively). The general pattern of variation in herbage accumulation described by the Fourier curves could also be observed from the results of seasonal accumulation of herbage presented in Table 8. During summer 1 , there was a clear contrast between treatments $95 / 50$ and $100 / 50$, with intermediate values recorded for treatments 95/30 and 100/30. Differences disappeared during autumn and winter, except for treatment $100 / 30$ that resulted in highest herbage accumulation during winter. In spring and early-summer 2 treatment $95 / 30$ accumulated more herbage than 95/50 ( $p=$ $0.0045)$, with intermediate values recorded for treatments $100 / 30$ and $100 / 50$, which did not differ from $95 / 30$.

\section{DISCUSSION}

In swards formed by tall, tufted-tropical grass species like Panicum maximum, variability within experimental units is important and needs to be taken into account when planning sampling procedures. The size, number and distribution of tussocks, associated with potential irregular distribution of herbage mass and leaf canopy height (Lopes, 2006) can contribute to high variability when simple random sampling procedures are used. For that reason, measurements in this experiment were made using a systematic sampling procedure (McIntyre, 1978; Mannetje, 2000) for leaf canopy height prior to any other measurement covering the entire area of each paddock. The results were used to identify representative areas of sward condi- 
Table 8 - Seasonal herbage accumulation of Mombaça grass swards subjected to rotational stocking managements from January 2001 to February 2002.

\begin{tabular}{|c|c|c|}
\hline \multirow{2}{*}{ Residue (cm) } & \multicolumn{2}{|c|}{ Sward light interception (\%) } \\
\hline & 95 & 100 \\
\hline \multicolumn{3}{|c|}{ Summer $1\left(\mathrm{~kg} \mathrm{ha}^{-1} \mathrm{DM}\right)^{1}$} \\
\hline 30 & $7810 \mathrm{AB}^{\prime}$ & $7110 \mathrm{AB}^{\prime}$ \\
\hline \multirow[t]{3}{*}{50} & $9480 \mathrm{~A}^{\prime}$ & $5450 \mathrm{~B}^{\prime}$ \\
\hline & \multicolumn{2}{|c|}{ s.e. $\mathrm{d}^{2}$. interaction $=1417$} \\
\hline & \multicolumn{2}{|c|}{ Autumn $\left(\mathrm{kg} \mathrm{ha}^{-1} \mathrm{DM}\right)$} \\
\hline 30 & $4120 \mathrm{~A}^{\prime}$ & $3970 \mathrm{~A}^{\prime}$ \\
\hline \multirow[t]{3}{*}{50} & $3480 \mathrm{~A}^{\prime}$ & $4180 \mathrm{~A}^{\prime}$ \\
\hline & \multicolumn{2}{|c|}{ s.e.d. interaction $=1611$} \\
\hline & \multicolumn{2}{|c|}{ Winter $\left(\mathrm{kg} \mathrm{ha}^{-1} \mathrm{DM}\right)$} \\
\hline 30 & $2060 \mathrm{~B}^{\prime}$ & $3580 \mathrm{~A}^{\prime}$ \\
\hline \multirow[t]{3}{*}{50} & $1460 \mathrm{~B}^{\prime}$ & $1870 \mathrm{~B}^{\prime}$ \\
\hline & \multicolumn{2}{|c|}{ s.e.d. interaction $=472$} \\
\hline & \multicolumn{2}{|c|}{ Spring $\left(\mathrm{kg} \mathrm{ha}^{-1} \mathrm{DM}\right)$} \\
\hline 30 & $8500 \mathrm{~A}^{\prime}$ & $7170 \mathrm{AB}^{\prime}$ \\
\hline \multirow[t]{6}{*}{50} & $4450 \mathrm{~B}^{\prime}$ & $6580 \mathrm{AB}^{\prime}$ \\
\hline & \multicolumn{2}{|c|}{ s.e.d. interaction $=1738$} \\
\hline & \multicolumn{2}{|c|}{ Early-Summer $2\left(\mathrm{~kg} \mathrm{ha}^{-1} \mathrm{DM}\right)$} \\
\hline & $5770 \mathrm{~A}^{\prime}$ & $4220 \mathrm{AB}^{\prime}$ \\
\hline & $2190 \mathrm{~B}^{\prime}$ & $3710 \mathrm{AB}^{\prime}$ \\
\hline & \multicolumn{2}{|c|}{ s.e.d. interaction $=1565$} \\
\hline
\end{tabular}

${ }^{1}$ Treatment means followed by the same upper case letter with (') within seasons are not different $(p>0.05) .{ }^{2}$ standard error of the difference.

tion at the time of sampling, and further sampling for herbage mass pre and post-grazing carried out at random on those areas. Overall, the coefficient of variation for herbage mass pre and post-grazing varied from 6 to $10 \%$ and for herbage accumulation was around $20 \%$. These are low when compared to values of 30 to $80 \%$ reported by Penati et al. (2005) in an experiment studying the number (two to nine), size ( 0.25 to $3.0 \mathrm{~m}^{2}$ ) and format (square and rectangular, with varying ratios between perimeter and area) of the frames used to sample herbage mass in Tanzânia guineagrass (Panicum maximum Jacq. cv. Tanzânia). This is an indication that the sampling procedure used here was effective in reducing variability in this experiment. Despite that, monitoring of the grazing process was very careful and paddocks remained visually homogeneous yet with differences between treatments throughout the experimental period. Herbage cuts were made at $20 \mathrm{~cm}$ from ground level, so did not take into account the material positioned at the base of the sward and comprised almost exclusively of stems and dead material. This impairs direct comparisons of the results from this experiment with other information available in the literature and recorded from cuts taken to ground level.

Grazing management modified leaf canopy height and sward herbage mass, the size and orientation of the light interception area (LIAI) and the proportion of leaf relative to stem and dead material. In general, the more lenient and less frequent defoliations associated with the $50 \mathrm{~cm}$ residue and the $100 \%$ LI pre-grazing condition resulted in taller swards (Figure 3 ), larger herbage mass (Tables 1 and 2) with lower proportion of leaf (Tables 3 and 4) and higher proportion of stem (Tables 5 and 6) and dead material (Table 7) positioned in a relatively more horizontal arrangement (Figure 5) than the more severe and frequent defoliations associated with the $30 \mathrm{~cm}$ residue and the 95\% LI pre-grazing condition.

Targets of post-grazing residue were relatively easy to maintain when paddocks were grazed at $95 \%$ LI, but at $100 \%$ LI post-grazing residues increased over the course of the experiment, particularly when the target was $30 \mathrm{~cm}$. This was a likely consequence of the difficulty of grazing due to the accumulation of dead material, particularly stems, in the lower strata of the swards (Table 6). Leaf canopy height pre-grazing was $86.7,87.2,91.7$ and $89.2 \mathrm{~cm}$ for the $95 \% \mathrm{LI}$ and $109.8,110.4,116,9$ and $124.3 \mathrm{~cm}$ for the $100 \%$ LI treatments in summer 1, autumn-winter, spring and early summer 2 , respectively. There was some variation for the $100 \%$ LI treatments $(14.5 \mathrm{~cm} \cong 13 \%)$, but leaf canopy height pre-grazing was around 90 and 115 $\mathrm{cm}$ for the $95 \%$ and $100 \%$ LI treatments, respectively, throughout the year, regardless of swards being vegetative or reproductive (Figure 3). This was probably a consequence of the way measurements of leaf canopy height were made, relating them to the upper surface of the leaf canopy, irrespective of the height of associated seed heads (Carnevalli et al., 2006). This definition was objective, with a high consistency of readings taken by different observers. Barbosa (2004), working with Tanzânia guinegrass, found that 95 and $100 \%$ LI corresponded with leaf canopy heights of 70 and $85 \mathrm{~cm}$, respectively, and Mello \& Pedreira (2004) for the same forage plant managed under irrigation and high input of nitrogen fertiliser $\left(640 \mathrm{~kg} \mathrm{ha}^{-1} \mathrm{~N}\right)$, found that $95 \%$ LI corresponded to a leaf canopy height of $70 \mathrm{~cm}$. This indicates consistency and highlights the potential use of leaf canopy height as a field guide for monitoring and controlling grazing management in a similar manner to that for temperate forage species (Hodgson, 1990; Hodgson et al., 1994; Hodgson \& Da Silva, 2002).

The use of the LAI 2000 canopy analyser is normally recommended for measurements of leaf area index (LAI) and not light interception, even though it 
calculates LAI from the proportion of light measured at the base (ground level) in relation to that incident at the top of the sward. Estimates of LAI from this equipment are precise and reliable when dealing with annual crops and measurements are made during the vegetative phase of development (Welles \& Norman, 1991). In tropical swards, and probably for annual crops where sward canopy has senescing leaves and flowering stems, estimates are compromised because other plant components than leaves intercept the incident light (stems and senescent/dead material), causing the equipment to overestimate LAI (Sbrissia \& Da Silva, 2008). The canopy analyser can be used under diffuse light conditions, allowing for more flexibility and higher frequency of monitoring of sward light interception in field conditions.

Herbage mass pre-grazing was stable for the 95\% LI but increased for the $100 \%$ LI treatments as the experiment progressed, a result of the combined accumulation of stem and dead material on swards grazed at 100\% LI (Tables 5 and 7). The proportion of leaf decreased and that of stem and dead material increased from summer 1 to autumn-winter following the reproductive development of swards and the beginning of the dry season early in the autumn (Figure 1). This was particularly the case on the $100 \%$ LI treatments, the consequence of more intense flowering. Similar results were reported by Santos et al. (1999); Santos et al. (2004); Barbosa (2004); Cândido et al. (2005) and Lopes (2006) for rotationally stocked mombaça and tanzânia guineagrass and by Braga et al. (2006) for marandu palisadegrass (Brachiaria brizantha (A. Rich.) Stapf cv. Marandu). Treatment 95/30 resulted in the most effective control of flowering in late summer/early autumn, followed by $95 / 50$, 100/30 and 100/50 (Carnevalli et al., 2006), demonstrating that pre-grazing mass was more effective than post-grazing mass in controlling stem development, but could have its effectiveness augmented by more severe grazing (Carnevalli, 2003). This result is in keeping with those of Santos et al. (2006) on irrigated pasture of tanzânia guineagrass subjected to rotational stocking managements and high nitrogen fertiliser input (480 kg ha ${ }^{-1} \mathrm{~N}$ ), and those of Santos et al. (2004) and Cândido et al. (2005) with mombaça guineagrass under rotational stocking.

Summer was the season of highest proportion of stem in herbage mass post-grazing (Table 6), a result of active growth and high vegetative stem elongation rates common for most tropical grasses at that time of the year, particularly under the $100 \%$ LI treatments (Carnevalli, 2003; Santos et al., 2004; Cândido et al., 2005). Season of the year was a consistent feature influencing sward characteristics, the effect vary- ing with the post-grazing residue and/or pre-grazing canopy light interception levels used. This indicates the importance of multi-year studies when evaluating sward responses to grazing management and the potential carry-over effects on plant responses from one season to another.

Overall, around $24 \mathrm{t}$ of dry matter were harvested per hectare and swards grazed to $30 \mathrm{~cm}$ accumulated more herbage than those grazed to $50 \mathrm{~cm}$. More importantly, treatment effects were progressive and cumulative, resulting in higher herbage accumulation rates for $95 / 30$ in relation to other treatments, particularly $95 / 50$, during the second half of the experimental period (spring - early summer 2) (Figure 2 ). At the beginning of the experiment, in summer 1 , herbage accumulation responded mainly to variations in canopy light interception pre-grazing (Table 8). Less frequent defoliations during periods of active pasture growth, as illustrated by the $100 \%$ LI treatments in this experiment, are usually associated with high senescence and the risk of lower net accumulation in relation to more frequent defoliations $(95 \%$ LI treatments) (Carnevalli, 2003; Santos et al., 2004; Cândido et al., 2005). On the other hand, more frequent and harder grazing during the period of transition from vegetative to reproductive development, as represented by the $95 / 30$ treatment during summer, would decapitate elongating reproductive stems earlier in the season than in frequent but more lenient grazing $(95 / 50)$. This would allow for a short-term advantage in terms of dry matter accumulation for the 95/50 treatment, but later decapitation of reproductive stems in this treatment would tend to reduce growth potential and increase senescence losses in the following spring (Carnevalli, 2003), a pattern of response in keeping with that described by the Fourier series curves (Figure 2). The results of the ANOVA performed on data grouped within seasons showed the same general pattern (Table 8), indicating that this procedure was effective and did not affect the original assessment of response trends. The accumulation of dead material on swards grazed to $50 \mathrm{~cm}$ and/or at $100 \%$ LI during summer 1 and autumn resulted in lower herbage accumulation for the $50 \mathrm{~cm}$ than the $30 \mathrm{~cm}$ residue treatments in winter. This contrast persisted for the $95 \%$ LI treatments during spring and early summer 2 but disappeared for the $100 \%$ LI treatments (Table 8). The beginning of the new growth season in spring is usually characterised by the production of new basal tillers and death of old, surviving stems from late summer, autumn and winter, highlighting a period of high turnover in tiller population and canopy light interception area (Carnevalli, 2003). Under those circumstances, and within adequate limits of grazing frequency and 
intensity, defoliation strategies that result in low herbage mass post-grazing with high proportions of leaf, favouring the tillering process by allowing more light to penetrate into the sward, would result in higher rates of herbage accumulation and recovery of swards after grazing (Carnevalli, 2003).

Seasonality of herbage accumulation was a strong feature in this experiment and reflected the typical seasonal production of tropical grass species (Pedreira, 1973; Pedreira \& Mattos, 1981), one of the most challenging constraints to animal production on tropical pastures (Santos et al., 2006). Grazing management resulted in modifications in patterns (horizontal and vertical alignment of fitted Fourier curves) and magnitude (ratio between maximum and minimum accumulation rates for the 2000/2001 and 2001/2002 growing seasons) of seasonality that could be used to lessen constraints to animal production. The range of these modifications was larger than what is usually achieved by simply changing forage plants used and/ or genetic modifications of available species and cultivars. This indicates potential limitations of adopting standard pre-defined rest periods to control rotational stocking strategies, and highlights the importance of strategic use of forage conservation and supplementation practices when planning the use of forage plants.

Panicum maximum cv. Mombaça is quite flexible to grazing management, but there is a minimum period of time until the effect of grazing treatments can be perceived. Usually the responses to post-grazing height were detected earlier than those to grazing frequency (LI treatments), suggesting the importance of long term and multi-year experiments when dealing with aspects of grazing management. Grazing at 95\% LI resulted in better control of stem and dead material accumulation than grazing at $100 \% \mathrm{LI}$, and, when associated with a $30 \mathrm{~cm}$ post-grazing height, favoured a quick return to fast regrowth conditions in spring. Conversely, a high herbage mass during the transition from winter to spring normally associated with the $50 \mathrm{~cm}$ post-grazing height (treatment 95/50) resulted in decrease in herbage accumulation during the new growing season, which was only partially compensated by an increase in grazing interval (grazing at $100 \% \mathrm{LI}$ ). Application of the principles in follow up work (e.g. Silva, 2004; Difante, 2005; Barbosa et al., 2007; Pedreira et al., 2007) supports the results obtained in the current experiment.

\section{CONCLUSIONS}

Grazing frequency is a powerful tool for managing and controlling sward structure and grazing systems. However, a standard rest period is not effective in defining grazing management in field conditions since herbage accumulation rates of Panicum maximum cv. Mombaça vary significantly throughout the year. The use of a plant growth based criterion like sward light interception to define intervals between successive grazings dealt with this variability effectively, with grazing at $95 \%$ LI resulting in better control of sward structure and composition than grazing at $100 \%$ LI. This was consistently achieved when leaf canopy height pre-grazing was around $90 \mathrm{~cm}$, demonstrating the importance and the potential use of sward target-based grazing management practices. Current grazing management practices in Brazil are closer to the $100 / 50$ than the $95 / 30$ treatment of this study. Assuming the present results from a single year's experimentation of approximately $27 \%$ yield advantage for a $30 \mathrm{~cm}$ over a $50 \mathrm{~cm}$ post-grazing height, pastoral industries in Brazil will potentially make significant productivity gains from implementation of these findings.

\section{ACKNOWLEDGEMENTS}

To Professor Domício do Nascimento Júnior for valuable comments during the elaboration of this paper and to CNPq (Conselho Nacional de Desenvolvimento Científico e Tecnológico, Brazil) and FAPESP (Fundação de Amparo à Pesquisa do Estado de São Paulo, Brazil) for partial funding of this research.

\section{REFERENCES}

BARBOSA, R.A. Características morfofisiológicas e acúmulo de forragem em capim-tanzânia (Panicum maximum Jacq. cv. Tanzânia) submetido a freqüências e intensidades de pastejo. Viçosa: Universidade Federal de Viçosa, 2004. 122p. Tese (Doutorado).

BARBOSA, R.A.; NASCIMENTO JÚNIOR, D.; EUCLIDES, V.P.B.; DA SILVA, S.C.; ZIMMER, A.H; TORRES JÚNIOR, R.A.A. Capim-tanzânia submetido a combinações entre intensidade e frequência de pastejo. Pesquisa Agropecuária Brasileira, v.42, p.329-340, 2007.

BRAGA, G.J.; PEDREIRA, C.G.S.; HERLING, V.R.; LUZ, P.H.C.; LIMA, C.G. Sward structure and herbage yield of rotationally stocked pastures of "Marandu" palisadegrass [Brachiaria brizantha (A. Rich.) Stapf] as affected by herbage allowance. Scientia Agricola, v.63, p.121-129, 2006.

CÂNDIDO, M.J.D.; GOMIDE, C.A.M.; ALEXANDRINO, E.; GOMIDE, J.A.; PEREIRA, W.E. Morfofisiologia do dossel de Panicum maximum cv. Mombaça sob lotação intermitente com três períodos de descanso. Revista Brasileira de Zootecnia, v.2, p.406-415, 2005

CARNEVALLI, R.A. Dinâmica da rebrotação de pastos de capimmombaça submetidos a regimes de desfolhação intermitente. Piracicaba: USP/ESALQ, 2003. 136p. Tese (Doutorado).

CARNEVALLI, R.A.; DA SILVA, S.C.; BUENO, A.A.O.; UEBELE, M.C.; BUENO, F.O.; HODGSON, J.; SILVA, G.N.; MORAIS, J.P. Herbage production and grazing losses in Panicum maximum cv. Mombaça under four grazing managements. Tropical Grasslands, v.40, p.165-176, 2006. 
DA SILVA, S.C. Understanding the dynamics of herbage accumulation in tropical grass species: the basis for planning efficient grazing management practices. In: INTERNATIONAL SYMPOSIUM ON GRASSLAND ECOPHYSIOLOGY AND GRAZING ECOLOGY, 2., Curitiba, 2004. Proceedings. Curitiba: Universidade Federal do Paraná, 2004. CD-ROM.

DA SILVA, S.C.; CARVALHO, P.C.F. Foraging behaviour and herbage intake in the favourable tropics/sub-tropics. In: McGILLOWAY, D.A. (Ed.) Grassland: a global resource. Wageningen: Wageningen Academic, 2005. p.81-95.

DIFANTE, G.S. Desempenho de novilhos, comportamento ingestivo e consumo voluntário em pastagem de Panicum maximum Jacq. cv. Tanzânia. Viçosa: Universidade Federal de Viçosa, 2005. 74p. Tese (Doutorado).

EMPRESA BRASILEIRA DE PESQUISA AGROPECUÁRIA. Serviço Nacional de Levantamento e Conservação de Solos. Sistema brasileiro de classificação de solos. Brasília: Embrapa Produção e Informação, 1999. 412 p.

FOOD AND AGRICULTURE ORGANIZATION - FAO. World reference base for soil resources 2006: a framework for international classification, correlation and communication. Rome: FAO, 2006. 145p. (World Soil Resources Report, 103).

GOMIDE, J.A. Morphogenesis and growth analysis of tropical grasses. In: INTERNATIONAL SYMPOSIUM ON ANIMAL PRODUCTION UNDER GRAZING, Viçosa, 1997. Proceedings. Viçosa: Universidade Federal de Viçosa, 1997. p.97-116.

HARDY, M.B.; MEISSNER, H.H.; O'REAGAIN, P.J. Forage intake and free-ranging ruminants: a tropical perspective. In: INTERNATIONAL GRASSLAND CONGRESS, 18., Winnipeg, 1997. Proceedings. Winnipeg: Canadian Grassland Association, 1997. p.45-52.

HODGSON, J. The significance of sward characteristics in the management of temperate sown pastures. In: INTERNATIONAL GRASSLAND CONGRESS, 15., Kyoto, 1985. Proceedings. Kyoto: Japanese Society of Grassland Science, 1985. p.63-66.

HODGSON, J. Grazing management: science into practice. Essex: Longman Scientific and Technical, 1990. 203p.

HODGSON, J.; CLARK, D.A.; MITCHELL, R.J. Foraging behaviour in grazing animals and its impact on plant communities. In: FASHEY JR, G.C.; COLLINS, M.; MERTENS, D.R.; MOSER, L.E. (Ed.) Forage quality, evaluation, and utilization. Madison: American Society of Agronomy, 1994. p.796-827.

HODGSON, J.; DA SILVA, S.C. Options in tropical pasture management. In: REUNIÃO ANUAL DA SOCIEDADE BRASILEIRA DE ZOOTECNIA, 39., Recife, 2002. Proceedings. Brasília: Sociedade Brasileira de Zootecnia, 2002. p. 180-202.

JANK, L.; VALLE, C.B.; RESENDE, R.M.S. Grass and forage improvement in the tropics and sub-tropics. In: McGILLOWAY, D.A. (Ed.) Grassland: a global resource, Wageningen: Wageningen Academic, 2005. p.69-80.

LAMBERT, M.G.; CLARK, D.A.; COSTALL, D.A. Influence of fertilizer and grazing management on North Island moist hill country. 2. Pasture botanical composition. New Zealand Journal of Agricultural Research, v.29, p.1-10, 1986.

LI-COR BIOSCIENCES. Plant canopy analyzer: LAI 2000; operating manual. Lincoln: LI-COR Biosciences, 1992. 179p.

LOPES, B.A. Características morfofisiológicas e acúmulo de forragem em capim-mombaça submetido a regimes de desfolhação. Viçosa: Universidade Federal de Viçosa, 2006. 188p. Tese (Doutorado).

MANNETJE, L. t'. Measuring biomass of grassland vegetation. In: MANNETJE, L.'T; JONES, R.M. (Ed.) Field and laboratory methods for grassland and animal production research. Wallingford: CABI, 2000. p.151-177.
MANNETJE, L. t'. Problems of animal production from tropical pastures. In: HACKER, J.B. (Ed.) Nutrional limits to animal production from pastures. Slough: Commonwealth Agricultural Bureaux , 1982. p.67-85.

McINTYRE, G.A. Statistical aspects of vegetation sampling. In: MANNETJE, L.t' (Ed.) Measurement of grassland vegetation and animal production. Farnham Royal: Commonwealth Agricultural Bureaux, 1978. p.8-21.

MELLO, A.C.L.; PEDREIRA, C.G.S. Respostas morfológicas do capim-Tanzânia (Panicum maximum Jacq. cv. Tanzânia-1) irrigado à intensidade de desfolha sob lotação rotacionada. Revista Brasileira de Zootecnia, v.33, p.282-289, 2004.

PEDREIRA, B.C.; PEDREIRA, C.G.S.; DA SILVA, S.C. Estrutura do dossel e acúmulo de forragem de Brachiaria brizantha cv. Xaraés em resposta a estratégias de pastejo. Pesquisa Agropecuária Brasileira, v.42, p.281-287, 2007.

PEDREIRA, J.V.S. Crescimento estacional dos capins Colonião Panicum maximum Jacq., Gordura Melinis minutiflora Pal de Beauv, Jaraguá Hyparrhenia rufa (Ness) Stapf e Pangola de Taiwan A-24 Digitaria pentzii Stent. Boletim de Indústria Animal, v.30, p.59-145, 1973.

PEDREIRA, J.V.S.; MATTOS, H.B. Crescimento estacional de vinte e cinco espécies ou variedades de capins. Boletim de Indústria Animal, v.38, p.117-143, 1981.

PENATI, M.A.; CORSI, M.; LIMA, C.G.; MARTHA JÚNIOR, G.B.; DIAS, C.T.S. Número de amostras e relação dimensão:formato da moldura de amostragem para determinação da massa de forragem de gramíneas cespitosas. Revista Brasileira de Zootecnia, v.34, p.36-43, 2005.

RAIJ, B. VAN; QUAGGIO, J.A.; SILVA, N.M. Extraction of phosphorus, potassium, calcium, and magnesium from soils by ion-exchange resin procedure. Communications in Soil Science and Plant Analysis, v.17, p.547-566, 1986.

SANTOS, P.M.; CORSI, M.; BALSALOBRE, M.A.A. Efeito da freqüência de pastejo e da época do ano sobre a produção e a qualidade em Panicum maximum cvs. Tanzânia e Mombaça. Revista Brasileira de Zootecnia, v.28, p.244-249, 1999.

SANTOS, P.M.; CORSI, M; BALSALOBRE, M.A.A. Características morfogenéticas e taxa de acúmulo de forragem do capimMombaça submetido a três intervalos de pastejo. Revista Brasileira de Zootecnia, v.33, p.843-851, 2004.

SANTOS, P.M.; CORSI, M.; PEDREIRA, C.G.S.; LIMA, C.G. Tiller cohort development and digestibility in Tanzania guinea grass (Panicum maximum cv. Tanzania) under three levels of grazing intensity. Tropical Grasslands, v.40, p.84-93, 2006.

SBRISSIA, A.F.; DA SILVA, S.C. Comparação de três métodos para estimativa do índice de área foliar em pastos de capim-marandu sob lotação contínua. Revista Brasileira de Zootecnia, v. 37, p.212-220, 2008.

SILVA, A.L.P. Estrutura do dossel e o comportamento ingestivo de novilhas leiteiras em pastos de capim Mombaça. Curitiba: Universidade Federal do Paraná, 2004. 104p. Tese (Doutorado).

WELLES, J.M.; NORMAN, J.M. Instrument for indirect measurement of canopy architecture. Agronomy Journal, v.83, p.818-825, 1991.

WOLFINGER, R.D. Covariance structure selection in general mixed models. Communications in Statistics Simulation and Computation, v.22, p.1079-1106, 1993.

Received October 18, 2007

Accepted June 17, 2008 